\title{
Polyploid cells in blastocysts and early fetuses from Australian Merino sheep
}

\author{
J. D. Murray, C. Moran*, M. P. Boland†, C. D. Nancarrow, R. Sutton, \\ R. M. Hoskinson and R. J. Scaramuzzi \\ CSIRO, Division of Animal Production, PO Box 239, Blacktown, New South Wales 2148, and \\ * Department of Animal Husbandry, University of Sydney, Sydney, New South Wales 2006, \\ Australia
}

\begin{abstract}
Summary. Cytogenetic examination was made of 103 13-14-day-old blastocysts and 116 24-32-day-old fetuses from untreated and androstenedione-7-HSA-immunized Merino ewes. There were no differences in the chromosome composition of blastocysts or fetuses from treated or untreated ewes and so the data were combined. At Days 13-14 a $1 \mathrm{~N} / 2 \mathrm{~N}$ mosaic and a $2 \mathrm{~N}-1 / 2 \mathrm{~N} / 4 \mathrm{~N}$ mosaic embryo were observed. In addition, 52 of the blastocysts were $2 \mathrm{~N} / 4 \mathrm{~N}$ mosaics, with 8 of these also containing $8 \mathrm{~N}$ cells, and one blastocyst was a $2 \mathrm{~N} / 8 \mathrm{~N}$ mosaic. No aneuploid fetuses were observed, but 80 of the 116 fetuses contained polyploid cells, including $4 \mathrm{~N}, 6 \mathrm{~N}$ and $8 \mathrm{~N}$ cells. The polyploid cells observed in the blastocysts and fetuses should not be considered as abnormal cells as they appear to be a normal part of the developmental processes leading to trophoblast formation and fetal differentiation.
\end{abstract}

\section{Introduction}

Many factors have been implicated in early embryonic mortality in domestic animals (Edey, 1969) including chromosomal abnormalities (Gustavsson, 1980). Estimates of the frequency of early embryonic loss attributable to chromosomal imbalances range from 6 to $11 \%$ in sheep (Long \& Williams, 1980; Murray et al., 1985), cattle (Gayerie de Abreu, Lamming \& Shaw, 1984) and pigs (McFeely, 1967). Most of these losses occur before Day 12 of gestation as the level of aberrant embryos was $1.9 \%$ in a sample of 159 Day-12-18 preimplantation cattle blastocysts (Hare et al., 1980) and no chromosomally abnormal embryos were observed in a sample of 75 Day-13-18 sheep blastocysts (Long, 1977).

A confounding problem in interpreting the chromosomal normality of preimplantation blastocysts is the occurrence of polyploid cells in the trophoblast (Barlow, Owen \& Graham, 1972). Day 6 mouse blastocysts have trophoblast cells with $16-32 \mathrm{~N}$ ploidy levels, with some trophoblast cells of Day 11 fetuses giving a DNA content up to 850 times the haploid level (Barlow \& Sherman, 1972). However, the total number of polyploid cells at Day 11 would only be $10-15 \%$ of the total cells in the trophoblast. Polyploid cells have also been reported in preimplantation blastocysts of some livestock species. Hare et al. (1980) reported that $41 \cdot 5 \%(66 / 159)$ of the Day $12-18$ cattle blastocysts analysed were $2 \mathrm{~N} / 4 \mathrm{~N}$ mosaics, while 2 blastocysts were $2 \mathrm{~N} / 3 \mathrm{~N}$ and $2 \mathrm{~N} / 6 \mathrm{~N}$. The $2 \mathrm{~N} / 4 \mathrm{~N}$ mosaic blastocysts observed were in the 14-18-day-old age range, with none of the 12- and 13-day-old embryos showing 2N/4N mosaicism. Long \& Williams (1982), working with Day-10 pig blastocysts, demonstrated that the incidence of $2 \mathrm{~N} / 4 \mathrm{~N}$ mosaicism was $41.9 \%$ in entire embryos as compared to $36 \cdot 1$ and $5 \cdot 17 \%$ in isolated trophoblast and inner cell mass cells respectively. Entire

† Present address: Department of Agriculture, University College, Dublin, Lyons, Newcastle P.O., Ireland. 
embryos $(19 \cdot 4 \%)$ and isolated trophoblast $(11 \cdot 1 \%)$, but not inner cell mass cells, also yielded cells with $2 \mathrm{~N}, 4 \mathrm{~N}$ and $8 \mathrm{~N}$ chromosome counts. Polyploidy was not reported in Day-13-18 sheep blastocysts (Long, 1977).

In the present study the occurrence of chromosome abnormalities and the incidence of polyploid cells in 13-14-day-old blastocysts and 24-32-day-old fetuses in a sample of Australian Merino sheep were investigated. This study is a continuation of the work previously reported on the incidence of chromosome abnormalities in Day-2 embryos from Merino sheep (Murray et al., 1985). A preliminary report noted the occurrence of the $2 \mathrm{~N}-1 / 2 \mathrm{~N} / 4 \mathrm{~N}$ mosaic and 5 complex heteroploids in a smaller sample of these blastocysts and fetuses (Boland et al., 1984).

\section{Materials and Methods}

Medium-wool Merino ewes were synchronized in the previous oestrous cycle using progestagenimpregnated sponges (Repromap: Upjohn Pty. Ltd, Rydalmere, New South Wales, Australia) and left untreated $(\mathrm{N}=78)$ or immunized against androstenedione-7-human serum albumin (Fecundin: Glaxo Animal Health Pty. Ltd, Boronia, Victoria, Australia). Two injections of androstenedione-7-HSA were given, with the second (booster) injection given 28 days after the primary injection and $14(\mathrm{~N}=46)$ or $25(\mathrm{~N}=64)$ days before expected mating. Ewes were exposed to 2 relays of harnessed Merino rams ( $1 \mathrm{ram} / 15$ ewes), which were alternated at the morning and evening checks for oestrus. More detailed descriptions of the animal handling methods and full reproductive data will be published elsewhere (Boland et al., 1986).

Ewes were slaughtered at $13-14(\mathrm{~N}=103)$ or $24-32(\mathrm{~N}=85)$ days after mating. Embryos were collected at Days 13-14 by flushing each uterine horn with $15 \mathrm{ml}$ phosphate-buffered saline (PBS: $0 \cdot 1 \mathrm{M}, \mathrm{pH} 7 \cdot 8$ ), while 24-32-day-old fetuses were removed from the uterine horns and dissected free of membranes.

Embryos were cultured in PBS containing 15\% heat-inactivated sheep serum, $0.8 \mu \mathrm{g}$ colchicine/ $\mathrm{ml}, 100$ i.u. penicillin $\mathrm{G} / \mathrm{ml}$ and $100 \mu \mathrm{g}$ streptomycin sulphate $/ \mathrm{ml}$ for $1-1.75 \mathrm{~h}$ at $37^{\circ} \mathrm{C}$ in a $5 \% \mathrm{CO}_{2}$ atmosphere. Embryos $>15 \mathrm{~mm}$ long were processed for chromosomes by the method of Hare $e t$ al. (1980), while embryos $<15 \mathrm{~mm}$ in length were harvested by a modification of the method of Shaw, Webb \& Wilkinson (1976) following $10 \mathrm{~min}$ in hypotonic medium $(0.075 \mathrm{M}-\mathrm{KCl})$. Embryos were removed from the hypotonic solution and placed on a dry slide with the excess medium being removed. Methanol:acetic acid fixative (3:1 v/v; $1-2$ drops) was placed on the embryo and the cells were then immediately dispersed over the slide by gently tapping the embryo with the polished, flat end of a 4-mm diameter brass rod.

Entire 24- to 32-day-old fetuses, dissected free of most membranes, were placed in the colchicine medium, finely minced with scissors and aspirated through an 18-gauge and then a 21-gauge needle. The cell suspension was incubated for $1-1.75 \mathrm{~h}$ and harvested by standard cytological methods. Cells were dropped onto cold, wet slides and air dried.

Chromosome preparations were stained in 5\% Giemsa in $0.004 \mathrm{M}$-phosphate buffer (pH 6.8) for $3.5 \mathrm{~min}$, air dried and mounted in DePeX. When possible the chromosomes of 10 diploid (2N) cells were counted from each individual, with the number and ploidy level of any polyploid cells encountered also being recorded.

\section{Results}

\section{Embryos at 13-14 days}

Chromosome counts were obtained from 103 of the 146 embryos (70.5\%) processed on Days 13 or 14 after mating (Table 1). The data are based on the analysis of 587 cells composed of $4692 \mathrm{~N}$ 
Table 1. Chromosome composition of cells from 13-14 day old Merino embryos

\begin{tabular}{|c|c|c|c|c|c|c|c|c|}
\hline \multirow{2}{*}{$\begin{array}{l}\text { Treatment } \\
\text { group }\end{array}$} & \multicolumn{2}{|c|}{ No. of embryos } & \multicolumn{6}{|c|}{ Chromosome complement } \\
\hline & Processed & Scored & $1 N / 2 N$ & $2 \mathrm{~N}$ & $2 \mathrm{~N} / 4 \mathrm{~N}$ & $2 \mathrm{~N}-1 / 2 \mathrm{~N} / 4 \mathrm{~N}$ & $2 \mathrm{~N} / 4 \mathrm{~N} / 8 \mathrm{~N}$ & $2 \mathrm{~N} / 8 \mathrm{~N}$ \\
\hline Control & 51 & 39 & 0 & 14 & 19 & 1 & 4 & 1 \\
\hline \multicolumn{9}{|l|}{ Immunized* } \\
\hline 14 days & 42 & 22 & I & 12 & 9 & 0 & 0 & 0 \\
\hline 25 days & 53 & 42 & 0 & 23 & 15 & 0 & 4 & 0 \\
\hline Total & 146 & 103 & 1 & 49 & 43 & 1 & 8 & 1 \\
\hline
\end{tabular}

* Ewes immunized against androstenedione-7-HSA with booster injection given 14 or 25 days before expected mating.
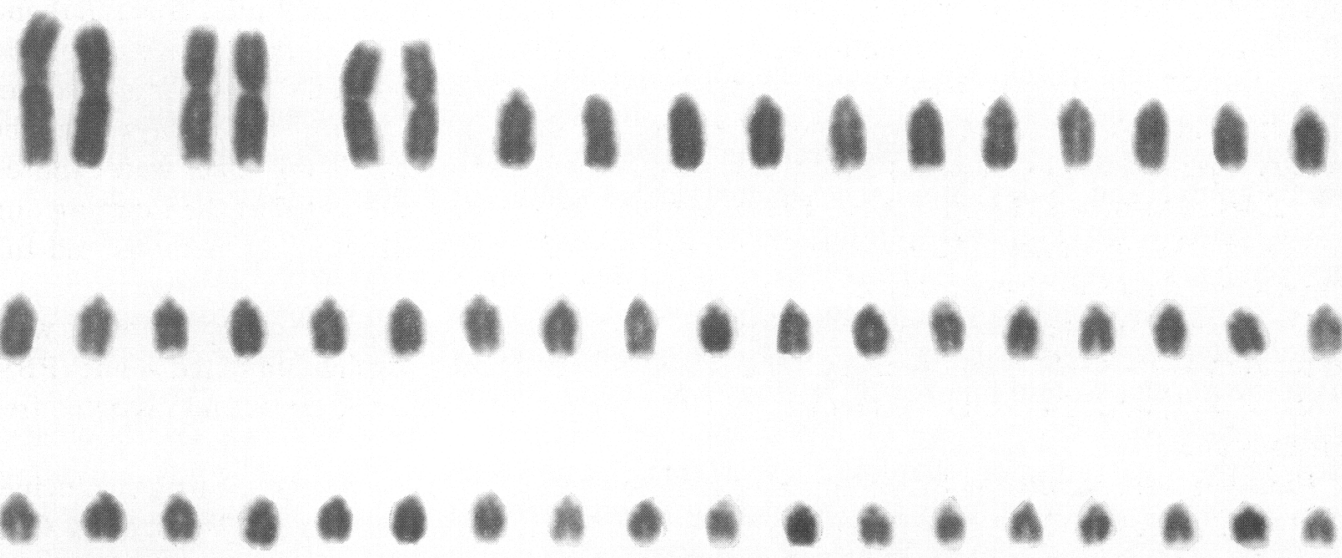

Fig. 1. Karyotype of $2 \mathrm{~N}=53$ monosomic cell from the $2 \mathrm{~N}-1 / 2 \mathrm{~N} / 4 \mathrm{~N}$ mosaic. $\times 1800$.
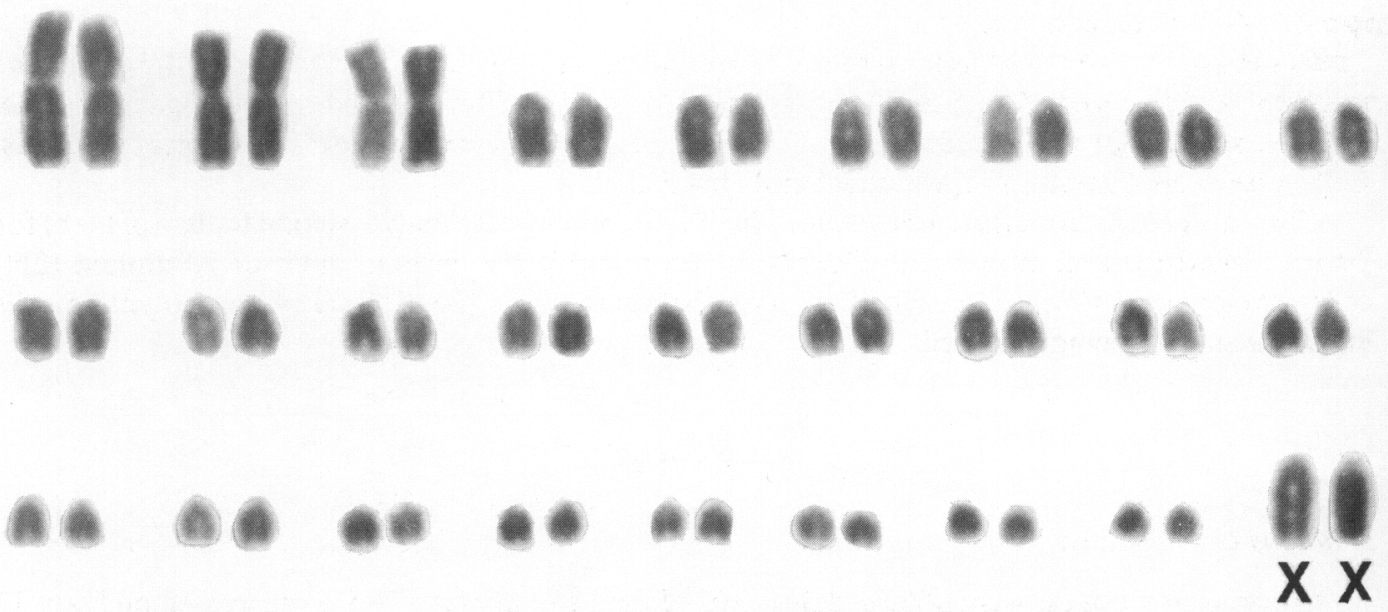

Fig. 2. Karyotype of a normal $2 \mathrm{~N}=54$ cell from the same individual as shown in Fig $1 . \times 2100$. 


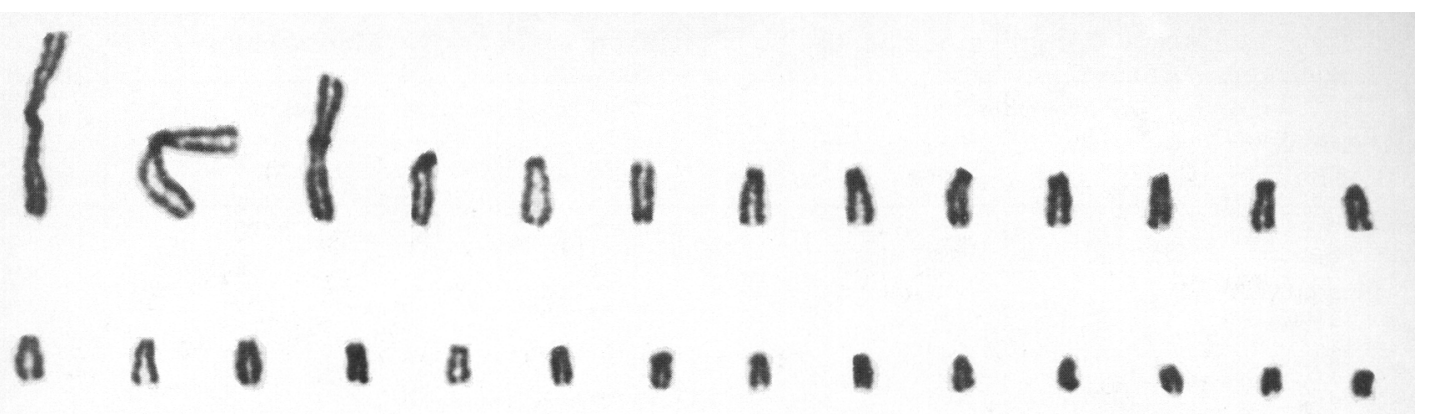

Fig. 3. Karyotype of the haploid cell from the $1 \mathrm{~N} / 2 \mathrm{~N}$ mosaic. $\times 1400$.

cells, $974 \mathrm{~N}$ cells, $158 \mathrm{~N}$ cells, $11 \mathrm{~N}$ cell and $52 \mathrm{~N}-1$ aneuploid cells. Between 1 and $112 \mathrm{~N}$ cells were scored for each embryo (mean $=4 \cdot 6$ ), with 16 embryos yielding only one $2 \mathrm{~N}$ cell suitable for analysis.

The control and immunized groups were not significantly different with respect to the sex ratios

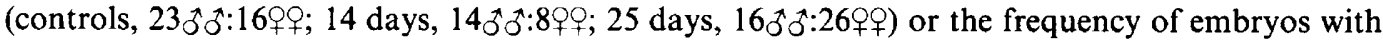
chromosomally abnormal or polyploid cells and therefore the data have been combined. However, both the control and 25-days immunized groups yielded significantly more embryos with analysable mitotic figures when compared with the 14-day group $\left(\chi_{1}^{2},=6.9, P<0.01\right.$ for both comparisons). The overall sex ratio was $53 \delta^{\star} \sigma^{*}: 50$ 우, which does not differ from the expected 1:1 ratio.

Cells from two embryos were scored as having unbalanced chromosome complements. A control embryo was assessed as a $2 \mathrm{~N}-1 / 2 \mathrm{~N} / 4 \mathrm{~N}$ mosaic based on 11 cells, 5 with 53 chromosomes, 4 with the normal diploid number of 54 (Figs $1 \& 2$ ) and 2 were $4 \mathrm{~N}$. The second chromosomally aberrant embryo came from the 14-days immunized group and was scored as a $1 \mathrm{~N} / 2 \mathrm{~N}$ mosaic based on the observation of 1 haploid $(\mathrm{N}=27)$ (Fig. 3) and $62 \mathrm{~N}=54$ cells. The possibility that these apparently abnormal cells are technical artefacts introduced during slide preparation was considered. The $2 \mathrm{~N}=53 / 2 \mathrm{~N}=54$ mosaic was accepted as real because of the high proportion of $2 \mathrm{~N}=53$ cells. Upon karyotyping, all 5 cells were found to be missing an unidentified acrocentric chromosome. All other cases with hypo- or hyper-diploid cells were interpreted as artefacts based on the failure to observe consistently the same numerical abnormality in more than 1 cell of the embryo. In addition to these abnormalities, one control embryo was observed with a chromatid break in 1 metacentric chromosome in 1 of the 9 diploid cells scored.

Polyploid cells were found in $51 \%$ of the embryos analysed. There was a tendency for more of the embryos from the control group to have polyploid cells than was observed in the 25 - or 14-days immunized groups (64 vs 45 and $41 \%$ respectively). Overall 44 embryos were $2 \mathrm{~N} / 4 \mathrm{~N}$ mosaics, 8

Table 2. Chromosome composition of cells from 24-32-day-old Merino fetuses

\begin{tabular}{|c|c|c|c|c|c|c|c|c|c|}
\hline \multirow[b]{2}{*}{$\begin{array}{l}\text { Treatment } \\
\text { group }\end{array}$} & \multicolumn{2}{|c|}{ No. of embryos } & \multicolumn{7}{|c|}{ Chromosome complement } \\
\hline & Processed & Scored & $2 \mathrm{~N}$ & $2 \mathrm{~N} / 4 \mathrm{~N}$ & $2 \mathrm{~N} / 6 \mathrm{~N}$ & $\underset{6 \mathrm{~N}}{2 \mathrm{~N} / 4 \mathrm{~N} /}$ & $2 \mathrm{~N} / 8 \mathrm{~N}$ & $\begin{array}{c}2 \mathrm{~N} / 4 \mathrm{~N} / \\
8 \mathrm{~N}\end{array}$ & $\begin{array}{l}2 \mathrm{~N} / 4 \mathrm{~N} / \\
6 \mathrm{~N} / 8 \mathrm{~N}\end{array}$ \\
\hline Control & 51 & 45 & 15 & 22 & 0 & 5 & 0 & 3 & 0 \\
\hline $\begin{array}{c}\text { Immunized* } \\
14 \text { days } \\
25 \text { days }\end{array}$ & $\begin{array}{l}27 \\
47\end{array}$ & $\begin{array}{l}25 \\
46\end{array}$ & $\begin{array}{r}7 \\
14\end{array}$ & $\begin{array}{l}11 \\
25\end{array}$ & $\begin{array}{l}0 \\
1\end{array}$ & $\begin{array}{l}4 \\
3\end{array}$ & $\begin{array}{l}0 \\
1\end{array}$ & $\begin{array}{l}2 \\
2\end{array}$ & $\begin{array}{l}1 \\
0\end{array}$ \\
\hline Total & 125 & 116 & 36 & 58 & 1 & 12 & 1 & 7 & 1 \\
\hline
\end{tabular}

* Ewes immunized against androstenedione-7-HSA with booster injection given 14 or 25 days before expected mating. 

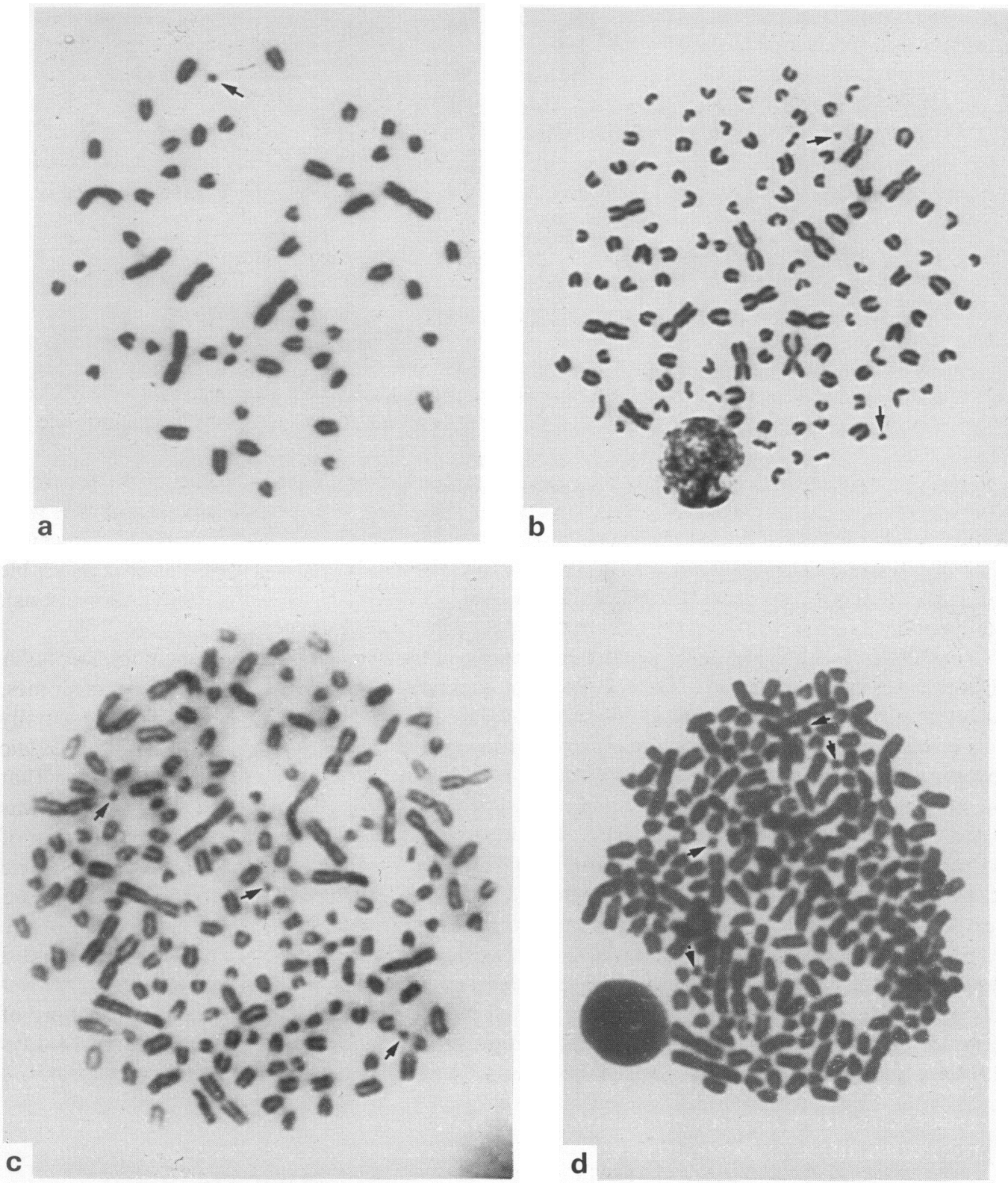

Fig. 4. Metaphase spreads of cells of various ploidies. Arrows indicate the $Y$ chromosome in each cell. (a) A $2 \mathrm{~N}$ cell. $\times 1820$. (b) A $4 \mathrm{~N}$ cell. $\times 1420$. (c) A $6 \mathrm{~N}$ cell. $\times 1390$. (d) A $8 \mathrm{~N}$ cell. $\times 1380$.

embryos were $2 \mathrm{~N} / 4 \mathrm{~N} / 8 \mathrm{~N}$ mosaics and 1 embryo was a $2 \mathrm{~N} / 8 \mathrm{~N}$ mosaic. The sex of the $4 \mathrm{~N}$ and $8 \mathrm{~N}$ cells was always the same as the $2 \mathrm{~N}$ cells observed in the same embryo.

Fetuses of 25-32 days

Chromosome counts were obtained from 116 of the $125(92 \cdot 8 \%)$ fetuses processed (Table 2). There were no significant differences between the control and treatment groups with respect to the 


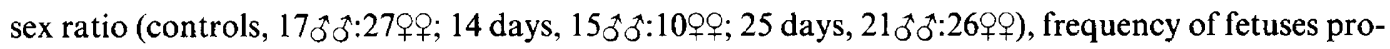
ducing chromosome spreads suitable for scoring or the proportion of fetuses containing polyploid cells, and therefore the data have been combined. A total of 1270 cells was scored (1087 2N; 154 $4 \mathrm{~N} ; 186 \mathrm{~N} ; 118 \mathrm{~N}$ ), with an average of $9.42 \mathrm{~N}$ cells being recorded per fetus. The sex ratio was $5333: 63$ 오, which does not differ from the expected 1:1 ratio.

Of the 9 fetuses that were not suitable for analysis 5 , including 2 degenerate ones, did not yield any mitotic figures. None of 116 fetuses for which chromosome counts were obtained were morphologically degenerate.

Mosaicism involving polyploid cells was observed in 80 fetuses $(69 \%)$. The majority of these fetuses $(72.5 \%)$ contained only $2 \mathrm{~N}$ and $4 \mathrm{~N}$ cells, while the remainder exhibited cells with higher ploidy levels. In two of the fetuses $4 \mathrm{~N}$ cells were not observed with one being $2 \mathrm{~N} / 6 \mathrm{~N}$ and the other $2 \mathrm{~N} / 8 \mathrm{~N}$. The remaining 20 fetuses were more complex heteroploids, containing cells with 3 or 4 different ploidy levels. The most common of these more complex heteroploids was the $2 \mathrm{~N} / 4 \mathrm{~N} / 6 \mathrm{~N}$ type (15\%). Representative cells from each ploidy level are illustrated in Fig. 4(a-d).

In addition to the fetuses, 3 sets of membranes that did not contain fetal material were processed. Two of the membrane remnants did not produce any mitotic figures suitable for analysis, while the third remnant was male and contained both $2 \mathrm{~N}$ and $4 \mathrm{~N}$ cells.

\section{Discussion}

These results indicate that the $11 \%$ chromosomally abnormal Day-2 embryos observed in an earlier phase of this study (Murray et al., 1985) are largely lost before Day 13 of development. This result is in agreement with previous reports on blastocysts from sheep (Long, 1977) and cattle (Hare et al., 1980) for which 0 and $1.9 \%$ respectively of the later-stage embryos were chromosomally aberrant, as compared with 6\% (Long \& Williams, 1980) and 7.2\% (Gayerie de Abreu et al., 1984) in early-stage embryos.

In our earlier study (Murray et al., 1985) 4 of the 8 abnormal Day- 2 embryos collected as part of this experiment were $1 \mathrm{~N} / 2 \mathrm{~N}$ mosaics. Of the 2 abnormal 13-14-day-old blastocysts observed in this study, 1 was assessed as a $1 \mathrm{~N} / 2 \mathrm{~N}$ mosaic based on a single $1 \mathrm{~N}$ cell. Assuming that this cell was not an artefact, this would indicate that some of the $1 \mathrm{~N} / 2 \mathrm{~N}$ mosaics observed at Day 2 are able to develop to the hatched blastocyst stage. However, work with induced mouse parthenogenotes indicates that most of these embryos would be expected to die before implantation (Kaufman, Barton \& Surani, 1977). The other abnormal embryo was a $2 \mathrm{~N}-1 / 2 \mathrm{~N} / 4 \mathrm{~N}$ mosaic, with an aneuploid abnormality most probably arising after fertilization through the loss of a chromosome from the metaphase plate during an early cleavage division. The consequences of aneuploid mosaicism are not known although it may not be incompatible with continued development and post-natal survival (Gustavsson, 1980). Mosaicism for sex chromosomes is known and one XO/XX ewe has been reported (Baylis, Wayte \& Owen, 1984).

The high proportion of Day 13-14 embryos containing polyploid cells (51\%) was unexpected, as Long (1977) reported no polyploid cells from 75 Day 13-18 New Zealand Romney $\times$ Scottish Blackface sheep blastocysts. This difference may be attributable to breed differences. The presence of $4 \mathrm{~N}$ cells is fairly common in hatched or expanded blastocysts of cattle (Hare et al., 1980) and pigs (Long \& Williams, 1982) and therefore the difference between Long's (1977) work and this study may reflect a difference in the rate of development of the blastocyst between the two breeds. The occurrence of octaploid cells in $8.7 \%$ of the Day 13-14 blastocysts is probably also a normal part of the polyploid progression seen in trophoblast cells (Barlow \& Sherman 1972). Long \& Williams (1982) reported a high level of $8 \mathrm{~N}$ cells in entire Day-10 pig embryos (19.4\%) and in isolated trophoblast cells (11.1\%), and Barlow \& Sherman (1972) have demonstrated cells with ploidy levels of up to $425 \mathrm{~N}$ in Day-11 mouse trophoblast cells. 
The polyploid cells observed in these Day 13-14 sheep embryos are probably not derived from the binucleate trophoblast cells which first appear at Day 16 in New Zealand Romney embryos (Boshier, 1969). These binucleate cells are thought to differentiate and migrate into the uterine epithelium (Wooding, 1982).

The origin of the polyploid cells observed in $69 \%$ of the 24-32-day fetuses examined is not known, but their occurrence should not be considered abnormal. The fetuses were dissected as free from membranes as possible, so these polyploid cells must be largely, if not exclusively, derived from fetal cells and therefore are not derived from the same cell lineages as the polyploid cells observed in the Day 13-14 blastocysts. The polyploid cells are presumably part of normal developmental processes as some differentiated tissues, such as the liver and salivary glands, are known to contain polyploid cells (Brodsky \& Uryvaeva, 1977). However, as the entire fetus was processed as one preparation for chromosome analysis, there is no information to suggest from which tissues the various types of polyploid cells arose.

The $4 \mathrm{~N}$ and $8 \mathrm{~N}$ cells could arise through endoreduplication of diploid cells to yield $4 \mathrm{~N}$ cells as occurs in trophoblast (Barlow \& Sherman, 1972), followed by a second round of endoreduplication to produce $8 \mathrm{~N}$ cells. Alternatively, these cells may go through a series of nuclear divisions with and without cytokinesis to yield a progression which includes binucleate cells; i.e. $2 \mathrm{~N}$ to $2 \times 2 \mathrm{~N}$ to $4 \mathrm{~N}$ to $2 \times 4 \mathrm{~N}$ to $8 \mathrm{~N}$. This is the route of polyploid cell formation in liver hepatocytes (Brodsky $\&$ Uryvaeva, 1977). A third route of polyploid cell formation may be via cell fusion, but in mammalian development cell fusion is considered rare (Brodsky \& Uryvaeva, 1977).

There are two possible origins for the $6 \mathrm{~N}$ cells reported in $8.3 \%$ of the fetuses. They could arise via the endoreduplication or binucleate cell routes from $3 \mathrm{~N}$ cells or by cell fusion. Fechheimer, Isakova \& Belyaev (1983) discuss the various possible origins of $3 \mathrm{~N}$ cells in diploid-triploid chimaeras, but all of the proposed mechanisms operate within the first few cleavage divisions. Thus $2 \mathrm{~N} / 3 \mathrm{~N}$ chimaeras should have been observed in at least $8.3 \%$ of the Day-2 (Murray et al., 1985) and the Day 13-14 embryos collected during this experiment. As no $2 \mathrm{~N} / 3 \mathrm{~N}$ chimaeras were observed in the earlier stage embryos, we conclude that the $6 \mathrm{~N}$ cells arose by cell fusion and as such represent evidence for the existence of this mode of polyploidization during embryogenesis. The $6 \mathrm{~N}$ cells could arise through the fusion of one diploid and one tetraploid cell or 3 diploid cells. Indeed, 2 trinucleate cells were observed in one fetus. More work is required to identify the tissues in which these polyploid cells occur and to elucidate their role in fetal differentiation.

We thank the animal house staff, in particular Mr J. Fenn, Mr J. Nobbs and Mr H. Thompson, for their assistance with the animals; and Mrs A. Dafter, Mr I. Hazelton, Mr N. Hamilton and Mr J. Marshall for technical assistance. M.P.B. was the recipient of a Reserve Bank of Australia Fellowship while on leave from University College, Dublin.

\section{References}

Barlow, P.W. \& Sherman, M.I. (1972) The biochemistry of differentiation of mouse trophoblast: studies on polyploidy. J. Embryol. exp. Morph. 27, 447-465.

Barlow, P.W., Owen, D.A.J. \& Graham, C. (1972) DNA synthesis in the preimplantation mouse embryo. $J$. Embryol. exp. Morph. 27, 431-445.

Baylis, M.S., Wayte, D.M. \& Owen, J.B. (1984) An $\mathrm{XO} / \mathrm{XX}$ mosaic sheep with associated gonadal dysgenesis. Res. Vet. Sci. 36, 125-126.

Boland, M.P., Murray, J.D., Scaramuzzi, R.J., Moran, C., Sutton, R., Hoskinson, R.M., Hazelton, I.G. \& Nancarrow, C.D. (1984) Reproductive wastage and early embryonic chromosomal abnormalities in immunized and control Merino ewes. In Reproduction in Sheep, pp. 137-139. Eds D. R. Lindsay \& D. T. Pearce. Australian Academy of Science, Canberra.

Boland, M.P., Nancarrow, C.D., Murray, J.D., Scaramuzzi, R.J., Sutton, R., Hoskinson, R.M. \& Hazelton, I.G. (1986) Fertilization and early embryonic development in androstenedione-immune Merino ewes. J. Reprod. Fert. 78, 432-431.

Boshier, D.P. (1969) A histological and histochemical examination of implantation and early placentome formation in the sheep. J. Reprod. Fert. 19, 51-61. 
Brodsky, W. Ya. \& Uryvaeva, I.V. (1977) Cell polyploidy: its relation to tissue growth and function. Int. Rev. Cytol. 50, 275-332.

Edey, T.N. (1969) Prenatal mortality in sheep; a review. Anim. Breed. Abstr. 37, 173-190.

Fechheimer, N.S., Isakova, G.K. \& Belyaev, D.K. (1983) Mechanisms involved in the spontaneous occurrence of diploid-triploid chimerism in the mink (Mustela vison) and chicken (Gallus domesticus). Cytogenet. Cell Genet. 35, 238-243.

Gayerie de Abreu, F., Lamming, G.E. \& Shaw, R.C. (1984) A cytogenetic investigation of early stage bovine embryos relation with embryo mortality. Proc. 10th Int. Congr. Anim. Reprod. \& A.I., Urbana; Brief commun. 2, 82, Abstr.

Gustavsson, I. (1980) Chromosome aberrations and their influence on the reproductive performance of domestic animals - a review. Z. Tierzücht. ZüchtBiol. 97, 176-195.

Hare, W.C.D., Singh, E.L., Betteridge, K.J., Eaglesome, M.D., Randall, G.C.B., Mitchell, D., Bilton, R.J. \& Trounson, A.O. (1980) Chromosomal analysis of 159 bovine embryos collected 12 to 18 days after estrus. Can. J. Genet. Cytol. 22, 615-626.

Kaufman, M.H., Barton, S.C. \& Surani, M.A.H. (1977) Normal post implantation development of mouse parthenogenetic embryos to the forelimb bud stage. Nature, Lond. 265, 53-55.
Long, S.E. (1977) Cytogenetic examination of preimplantation blastocysts of ewes mated to rams heterozygous for the Massey I $\left(\mathrm{t}_{1}\right)$ translocation. Cytogenet. Cell Genet. 18, 82-89.

Long, S.E. \& Williams, C.V. (1980) Frequency of chromosomal abnormalities in early embryos of the domestic sheep (Ovis aries). J. Reprod. Fert. 58, 197-201.

Long, S.E. \& Williams, C.V. (1982) A comparison of the chromosome complement of inner cell mass and trophoblast cells in Day-10 pig embryos. J. Reprod. Fert. 66, 645-648.

McFeely, R.A. (1967) Chromosome abnormalities in early embryos of the pig. J. Reprod. Fert. 13, 579-581.

Murray, J.D., Boland, M.P., Moran, C., Sutton, R., Nancarrow, C.D., Scaramuzzi, R.J. \& Hoskinson, R.M. (1985) Occurrence of haploid and haploiddiploid mosaic embryos in untreated and androstenedione-immune Australian Merino sheep. $J$. Reprod. Fert. 74, 551-555.

Shaw, D.D., Webb, G.C. \& Wilkinson, P. (1976) Population cytogenetics of the genus Caledia (Orthoptera: Acridinae). II. Variation in the pattern of C-banding. Chromosoma (Berl.) 56, 169-190.

Wooding, F.B.P. (1982) Structure and function of placental binucleate ('Giant') cells. Biblthca anat. 22, 134-139.

Received 4 February 1986 